\title{
PENGELOLAAN WILAYAH PESISIR DAN PULAU-PULAU KECIL DI INDONESIA (Dalam Perspektif Perlindungan Hukum bagi Hak-hak Ekonomi Masyarakat Tradisional)
}

\author{
Oleh \\ Nurul Fajri Chikmawati \\ Fakultas Hukum Universitas YARSI, Jakarta \\ Email: nurul.fajri@yarsi.ac.id
}

\begin{abstract}
Coastal zones and small islands are newly growing areas and they are potentially capable of increasing the welfare of the local people. Not only do they have the conservational functions but they also provide marine resources in the forms of goods and services. These enormous potentials should be managed by integrating inter-related sectors to sustainably make the most of it. To achieve this goal, the government issued the Law No. 27 of 2007 on Coastal Zones and Small Islands Management which is then revised by the Law No. 1 of 2014 on the same subject. This revision is due to the fact that the Integrated Coastal Management which was supposed to be featured by the former law seemed to fail. The indicators are that the synchronization of this law with the related others is still poor, and that the control over coastal-related issues which favors investors or business people has not been reformed, leaving local and traditional people unheard. This revised law is expected to give hope to the better accommodated rights of the local and traditional people, particularly the financially related rights in general, so that they are actively involved in planning, using, and monitoring the WP3K management.
\end{abstract}

Keywords: Management, Coastal, Small Islands

Abstrak
Wilayah pesisir dan pulau-pulau kecil merupakan wilayah perkembangan baru
yang memiliki potensi sangat besar bagi peningkatan kesejahteraan masyarakat,
khususnya masyarakat pesisir. Wilayah ini selain memiliki fungsi konservasi, juga
memiliki fungsi lain sangat penting bagi penyediaan barang dan jasa kelautan.
Potensi yang besar ini perlu dikelola dengan pendekatan terintegrasi antar sektor
agar keseluruhan fungsi dapat dimanfaatkan dengan baik dan berkelanjutan.
Untuk itu Pemerintah menerbitkan Undang-Undang No. 27 Tahun 2007 tentang
Pengelolaan Wilayah Pesisir dan Pulau-Pulau Kecil, yang kemudian direvisi
dengan Undang-Undang No. 1 Tahun 2014 atas Perubahan Undang-Undang
No.27 Tahun 2007 tentang Pengelolaan Wilayah Pesisir dan Pulau-Pulau Kecil
dengan alasan belum mewujudkan pendekatan Integrated Coastal Management,
yang ditandai dengan tidak adanya pembaharuan atas penguasaan dan
pengusahaan yang timpang dan adanya ketidaksinkronan dengan peraturan 
perundang-undang lainnya. Undang-Undang ini juga dianggap lebih mementingkan aspek investasi dan lebih berpihak kepada dunia usaha sehingga tidak ada ruang bagi masyarakat, khususnya masyarakat nelayan tradisional dan masyarakat adat dalam pengusulan rencana pengelolaan wilayah pesisir dan pulau-pulau kecil. Dengan adanya revisi maka diharapkan hak-hak masyarakat tradisional, khususnya hak-hak ekonomi secara umum diakomodir sejak dalam proses perencanaan, pemanfaatan dan pengawasan serta pengawasan terkait dengan pengelolaan WP3K.

Kata kunci: pengelolaan, pesisir, pulau-pulau kecil

\section{PENDAHULUAN}

Kekayaan sumber daya alam dan ekosistemnya ataupun gejala keunikan alam dan atau keindahan alam lainnya yang dimiliki oleh bangsa Indonesia merupakan karunia Tuhan Yang Maha Esa. Potensi sumber daya alam dan ekosistemnya tersebut perlu dikembangkan dan dimanfaatkan bagi sebesarbesarnya kesejahteraan rakyat sehingga tercapai keseimbangan antara perlindungan, pengawetan dan pemanfaatan lestari. Pengelolaan atas sumber daya alam di Indonesia secara konstitusional berpedoman ketentuan Pasal 33 ayat (3) dengan tetap memperhatikan Pasal 28H ayat (1) UUD 1945. Pasal 33 ayat (3) UUD 1945 menetapkan bahwa "Bumi dan air dan kekayaan alam yang terkandung di dalamnya dikuasai oleh Negara dan dipergunakan untuk sebesarbesarnya kemakmuran rakyat" sebagai bentuk pemenuhan atas hak dasar warga Negara sebagaimana diamanatkan dalam Pasal 28H ayat (1) bahwa "Setiap orang berhak hidup sejahtera lahir dan batin, bertempat tinggal, dan mendapatkan lingkungan hidup yang baik dan sehat serta berhak mendapatkan layanan kesehatan".

Dengan demikian dapat dikatakan bahwa pemanfaatan bumi, air dan kekayaan alam yang terkandung didalamnya dilaksanakan secara seimbang tetap memperhatikan prinsip kebersamaan, efisiensi berkeadilan, berkelanjutan, berwawasan lingkungan, kemandirian serta dengan menjaga keseimbangan kemajuan dan kesatuan ekonomi nasional. Undang-Undang Dasar 1945 dewasa ini telah mempertegas perannya, selain merupakan konstitusi politik juga merupakan konstitusi ekonomi. Melalui gagasan demokrasi politik dan ekonomi, 
maka seluruh sumberdaya politik dan ekonomi dikuasai oleh rakyat yang berdaulat yang dalam hal-hal tertentu pengurusannya diwakilkan kepada negara ${ }^{1}$.

Sejak kebijakan otonomi daerah diberlakukan, Daerah mulai memperhatikan potensi yang dimilikinya dan yang secara ekonomis dapat dikembangkan untuk meningkatkan kesejahteraan masyarakat. Beberapa daerah di Indonesia yang secara geografis memiliki wilayah pesisir dan pulau-pulau kecil menyadari betapa pentingnya pengelolaan kawasan tersebut untuk berbagai kegiatan baik yang bersifat ekonomis maupun konservasi dengan seimbang dan tepat. Kawasan pesisir dan pulau-pulau kecil memang merupakan wilayah yang memiliki keunikan tersendiri namun rentan terhadap terjadinya konflik kepentingan, ekonomi dan sosial serta berbagai persoalan lingkungan akibat pemanfaatan yang tidak didasarkan pada prinsip ekologis yang merupakan dasar pengelolaan sumberdaya secara berkelanjutan ${ }^{2}$.

Konflik kewenangan di wilayah pesisir dan pulau-pulau kecil dapat muncul ketika terjadi perubahan paradigma dalam pengelolaan sumber daya alam dalam yurisdiksi wilayah pemerintah lokal dalam kerangka desentralisasi kewenangan. Pada sumber daya alam yang sifatnya tidak lintas batas, hal tersebut barangkali tidak akan menimbulkan masalah yang terlalu besar mengingat jurisdiksinya relatif jelas. Namun pada sumber daya yang sifatnya lintas wilayah seperti sumber daya perikanan dan kelautan, hal ini memerlukan perhatian yang cermat mengingat kemungkinan timbulnya konflik kewenangan sangat besar ${ }^{3}$. Seperti telah diketahui bahwa sumber daya kelautan bersifat common property (milik bersama) dengan akses yang bersifat quasi open access. Istilah common property dalam sumber daya kelautan mengarah kepada pemilikan yang dilakukan di bawah kontrol pemerintah atau lebih mengarah kepada sifat sumber daya yang merupakan public domain. Mengingat pemanfaatan yang bersifat quasi open

\footnotetext{
${ }^{1}$ Jimly Asshiddiqie, Green Constitution: Nuansa Hijau Undang-Undang Dasar Negara Republik Indonesia Tahun 1945, (Jakarta: Rajawali Pers, 2009), hal. 81-82.

2 Ambo Tuwo, Pendekatan Ekologi dalam Pengelolaan Sumber Daya Pesisir dan Laut, dalam buku Membangun Sumber Daya Kelautan Indonesia, (Jakarta: IPB Press, 2013), hal. 147.

${ }^{3}$ Akhmad Fauzi, Kebijakan Perikanan dan Kelautan, (Jakarta: Gramedia Pustaka Utama, 2005), hal. 51.
} 
access maka setiap individu merasa berhak untuk mengeksplorasi sumber daya laut ${ }^{4}$. Ketika hak pemilikan belum terdefinisikan dengan jelas maka akan muncul benturan kepentingan antarindividu atau kelompok, khususnya masyarakat nelayan tradisional yang secara geografis paling erat hubungannya dengan wilayah pesisir sebagi pintu gerbang menuju laut lepas.

Masyarakat tradisional adalah masyarakat perikanan tradisional yang masih diakui hak tradisionalnya dalam melakukan kegiatan penangkapan ikan atau kegiatan lainnya yang sah di daerah tertentu yang berada dalam perairan kepulauan sesuai dengan kaidah laut internasional ${ }^{5}$. Masyarakat tradisional ini adalah anggota masyarakat yang bertempat tinggal tidak jauh dari pesisir yang sebagian besar berprofesi sebagai nelayan, petani (termasuk petani budi daya ikan dan rumput laut), pedagang dan profesi lainnya. Sebagai sebuah komunitas, secara umum kehidupan masyarakat yang tinggal di kepulauan bukan saja relatif terisolisi, tetapi secara tradisional juga tertinggal dibandingkan daerah sekitarnya, mobilitas vertikal masyarakat berjalan lambat, bersifat tradisional dan pilihan hidup yang tersedia umumnya sangat terbatas. Berbeda dengan masyarakat yang tinggal di daratan atau terlebih yang tinggal di kota-kota besar yang telah memiliki prasarana publik yang lengkap dan memiliki akses yang sangat tinggi terhadap informasi dan pasar. Masyarakat tradisional yang tinggal di wilayah kepulauan terbiasa hidup dalam keterbatasan fasilitas dan prasarana publik. Untuk memenuhi kebutuhan sehari-hari serta kebutuhan prasarana produksi mereka sebagian mereka penuhi dari hasil olahan sendiri, selebihnya mereka mengandalkan kiriman pasokan dari luar pulau yang datangnya tidak selalu tepat waktu karena sangat tergantung dari keberadaan alat transportasi laut dan cuaca.Tersedianya air bersih dan layanan kesehatan yang cukup dan memadai menjadi barang mewah bagi masyarakat ${ }^{6}$. Selain itu sistem zonasi laut seringkali disalah tafsirkan sebagai upaya untuk membatasi ruang gerak nelayan dalam

\footnotetext{
${ }^{4}$ Ibid., hal.52.

${ }^{5}$ Pasal 1.35 Undang-Undang Nomor 27 Tahun 2007 tentang Pengelolaan Wilayah Pesisir dan Pulau-pulau Kecil.

${ }^{6}$ Bagong Suyanto, Anatomi Kemiskinan dan Strategi Penanganannya, (Malang: In-Trans, 2013), hal. 98
} 
menangkap ikan dan karena kurangnya sosialisasi program pembangunan oleh pemerintah setempat sehingga masyarakat merasa tidak dilibatkan dalam perencanaan pembangunan kawasan di wilayahnya akibatnya keinginan-keinginan warga tidak terakomodir dengan baik.

Persoalan penurunan kualitas fisik lingkungan pesisir umumnya terjadi pada ekosistem mangrove, terumbu karang dan padang lamun. Terumbu karang yang dalam kondisi baik saat ini tidak lebih dari 30\% sedangkan area yang mengalami degradasi hamper merata terjadi di seluruh wilayah pesisir Indonesia. Beberapa kegiatan yang diduga menjadi penyebab erosi pantai adalah kegiatan penambangan pasir laut untuk kepentingan reklamasi, pembangunan pelabuhan, jetty, marina serta pembangunan hotel dan resort. Pencemaran wilayah pesisir terjadi karena akibat dari aktivitas di darat seperti limbah industri dan rumah tangga serta pertanian. Beberapa aktivitas di laut juga menjadi salah satu penyebab kerusakan lingkungan seperti kegiatan ptransportasi laut, termasuk transportasi kapal pengangkut minyak dan kegiatan pertambangan lepas pantai. Hal-hal inilah yang menyebabkan penurunan kualitas lingkungan perairan dan estetika pantai ${ }^{7}$.

Berdasarkan data hasil survey dari Badan Informasi Geospasial, yang dulu dikenal dengan nama Badan Koordinasi Survei dan Pemetaan Nasional (Bakorsurtanal) jumlah pulau-pulau kecil di Indonesia telah berkurang dari semula berjumlah 17.508 sekarang tinggal 13.466 pulau. Penurunan jumlah ini disebabkan pulau gosong tidak lagi dimasukkan sebagai pulau, karena tidak sesuai dengan definisi pulau yang dikeluarkan oleh Perserikatan Bangsa-Bangsa yaitu objek yang masih tampak terlihat saat air pasang, sedangkan pulau gosong hanya muncul ketika air laut surut dan tenggelam saat air laut pasang. Selain itu kerusakan ekosistem mangrove dan terumbu karang serta kegiatan penambangan pasir disekitar pulau juga dapat mengakibatkan berkurangnya pulau-pulau kecil. Data Kementerian Kelautan dan Perikanan pada Tahun 2011 menunjukkan bahwa sekitar 28 buah pulau kecil di Indonesia sudah tenggelam dan ada 24 pulau kecil

\footnotetext{
${ }^{7}$ Ridwan Lasabuda, "Pembangunan Wilayah Pesisir dan Lautan dalam Perspektif Negara Kepulauan Republik Indonesia”, Jurnal Ilmiah Platax, Vol.1-2 Januari 2013, hal. 96-97.
} 
yang terancam tenggelam. Beberapa pulau yang sudah tenggelam dan sudah terancam tenggelam tersebut 2 (dua) diantaranya pulau kecil terluar yang dijadikan Titik Dasar (TD) kepulauan Indonesia, yaitu Pulau Nipa ${ }^{8}$ (TD 190 dan 190A) dan Pulau Maratua ${ }^{9}$ (TD 039). Penyebab utama tenggelamnya pulau kecil di Indonesia adalah penambangan pasir dan abrasi pantai. Adapun abrasi pantai di Pulau Maratua ini disebabkan oleh gelombang tinggi dan banyaknya masyarakat yang membangun rumah di tepi pantai.

Kondisi-kondisi seperti ini perlu mendapatkan perhatian dalam pengelolaan kawasan pesisir dan pulau-pulau kecil sehingga pembangunan masyarakat yang berwawasan lingkungan dapat berjalan dengan baik.

\section{PEMBAHASAN}

\section{Tujuan dan Ruang Lingkup Undang-Undang No. 1 Tahun 2014 atas Perubahan Undang-Undang No.27 Tahun 2007 tentang Pengelolaan Wilayah Pesisir dan Pulau-Pulau Kecil}

Dalam konsep pembangunan berkelanjutan ada beberapa hal yang harus diperhatikan, yaitu: 1) adanya komitmen pada keadilan dan fairness. Prioritas pembangunan seyogianya diberikan kepada masyarakat dunia yang paling miskin dan setiap keputusan hendaknya mempertimbangkan keberadaan generasi yang akan datang; 2) adanya pandangan jauh kedepan yang menekankan prinsip-prinsip precautionary untuk mencegah degradasi lingkungan; 3) pembangunan berkelanjutan mengintegrasikan, memahami, dan bertindak dalam korelasi yang kompleks antara lingkungan, ekonomi dan masyarakat. Pembangunan lingkungan, pembangunan ekonomi dan keadilan masyarakat merupakan pilar utama dalam

\footnotetext{
${ }^{8}$ Pulau Nipa (Nipah) secara geografis terletak diantara Selat Philip dan selat utama (main street) dan secara administratif termasuk dalam wilayah Desa Pemping Kecamatan Belakang Padang Kota Batam Provinsi Kepulauan Riau. Pulau ini merupakan bagian dari gugusan Kepulauan Riau yang berada di bagian terluar Negara Kesatuan Republik Indonesia yang berbatasan langsung dengan negara Singapura. Luas pulau Nipah adalah 1,2 ha dan diharapkan setelah adanya reklamasi pantai Pulau Nipah maka luasnya akan bertambah menjadi 60 ha.

${ }^{9}$ Pulau Maratua merupakan salah satu pulau terluar Indonesia yang terletak di Laut Sulawesi dan berbatasan langsung dengan Negara Malaysia. Pulau Maratua ini secara administrative berada dalam wilayah Kabupaten Berau, Provinsi Kalimantan Timur. Luas pulau ini adalah 2.375 ha.
} 
pembangunan berkelanjutan ${ }^{10}$. Dengan demikian pembangunan ekonomi harus mempertimbangkan dampak pada segi sosial dan lingkungan yang diarahkan pada: 1) pembangunan sosial yang ditujukan pada pemberantasan kemiskinan struktural di beberapa bidang, seperti ketiadaan akses pendapatan, lapangan kerja, air minum, jasa energi, pemukiman, fasilitas kesehatan, pendidikan dan lain-lain; 2) pembangunan ekonomi pembangunan ekonomi harus mengubah pola produksi dan konsumsi yang tidak menopang keberlanjutan, terutama dalam penggunaan energi yang tidak efisien dan mencemarkan, penggunaan sumber daya alam secara boros. Konsumsi juga perlu diarahkan kepada upaya daur ulang bahan kemasan dan hemat minyak karbon; 3) penyelamatan dan perlindungan ekosistem serta fungsi lingkungan dari sumber daya alam terus dijaga agar mampu menopang proses pembangunan berkelanjutan ${ }^{11}$.

Indonesia merupakan Negara kepulauan yang memiliki luas wilayah perairan 5,8 juta km persegi, 17.508 pulau dan panjang garis pantai $81.000 \mathrm{~km}$. Dengan karunia sumberdaya pesisir dan lautan tersebut seyogyanya masyarakat mempunyai tingkat kesejahteraan yang mapan, terutama yang bermukim di wilayah pesisir dan kepulauan ${ }^{12}$. Namun sayangnya hingga saat ini sumber daya tersebut selain belum dapat dimanfaatkan secara optimal dan mengalami kerusakan akibat pemanfaatan yang tidak sesuai dengan prinsip-prinsip ekologis yang menjadi dasar pengelolaan sumberdaya alam secara berkelanjutan ${ }^{13}$.

Oleh sebab itu pada Juli Tahun 2007 Pemerintah menerbitkan Undang-Undang No. 27 Tahun 2007 tentang Pengelolaan Wilayah Pesisir dan Pulau-Pulau Kecil ( selanjutnya disingkat dengan UU-PWP3K. Pemerintah telah mencermati bahwa dalam kurun waktu satu dekade terakhir ini terdapat kecenderungan terjadinya kerusakan pada wilayah pesisir dan pulau-pulau kecil karena memang wilayah

10 Budi Winarno, Etika Pembangunan, (Yogyakarta: Center for Academic Publising Services (CAPS), 2013), hal. 320-321. hal, 321,

${ }^{11}$ Ibid., mengutip pendapat Emil Salim dalam buku Ratusan Bangsa Merusak Satu Bumi,

${ }^{12}$ Aris Baso, Revitalisasi Pemberdayaan Masyarakat Pesisir bagi Kesejahteraan Nelayan dalam buku Membangun Sumberdaya Kelautan Indonesia,(Bogor: IPB Press, 2013), hlm 75.

${ }^{13}$ Ambo Tuwo, Op. Cit., hlm 147. 
tersebut memang tergolong rentan akibat aktivitas orang dalam pemanfaatan sumber daya alam serta akumulasi dari berbagai kegiatan eksploitatif yang bersifat parsial atau sektoral di wilayah tersebut atau akibat dari peraturan perundang-undangan yang terkait dengan pemanfaatan sumber daya yang tidak berorientasi upaya pelestarian. Kerusakan juga dapat berasal dari terjadinya bencana alam yang melanda beberapa wilayah Indonesia, khususnya di wilayah pesisir dan perairan. Pemerintah juga menyadari bahwa sementara ini kesadaran akan nilai strategis dari pengelolaan WP3K secara berkelanjutan, terpadu, dan berbasis masyarakat relatif kurang. Kurang dihargainya hak masyarakat adat/lokal dalam pengelolaan sumberdaya WP3K seperti pranata Sasi, Mane'e, Panglima Laot, Awig-awig dan terbatasnya ruang masyarakat adat/lokal untuk berpartisipasi dalam pengelolaan sumber daya yang ada ${ }^{14}$.

Tujuan dari penyusunan Undang-Undang No. 27 Tahun 2007 tentang Pengelolaan Wilayah Pesisir dan Pulau-pulau Kecil ini adalah ${ }^{15}$ :

1. Untuk menyiapkan peraturan setingkat undang-undang mengenai pengelolaan WP3K khususnya yang menyangkut perencanaan, pemanfaatan, hak dan akses masyarakat, penanganan konflik, konservasi, mitigasi bencana, reklamasi pantai, rehabilitasi kerusakan pesisir, dan penjabaran konvensi-konvensi internasional terkait;

2. Untuk membangun sinergi dan saling memperkuat hubungan kerja antarlembaga Pemerintah baik di tingkat pusat maupun daerah yang terkait dengan pengelolaan WP3K sehingga tercipta hubungan yang harmonis dan mencegah serta memperkecil konflik pemanfaatan dan konflik kewenangan antarkegiatan di wilayah pesisir dan pulau-pulau kecil.

3. Untuk memberikan kepastian dan perlindungan hukum serta memperbaiki tingkat kemakmuran masyarakat pesisir dan pulau-pulau kecil melalui pembentukan peraturan yang dapat menjamin akses dan hak-hak masyarakat

\footnotetext{
${ }^{14}$ Penjelasan Undang-Undang No. 27 tahun 2007.

${ }^{15}$ Penjelasan Undang-Undang No. 27 tahun 2007.
} 
pesisir dan anggota masyarakat lainnya yang berkepentingan, termasuk pihak pengusaha.

Ruang lingkup dari pengaturan Undang-Undang ini meliputi berbagai tahapan kegiatan dalam suatu sistem pengelolaan yang meliputi tahap perencanaan, pengelolaan, serta tahap pengawasan dan pengendalian terkait dengan berbagai aktifitas yang akan diselenggarakan di wilayah pesisir dan pulaupulau kecil, yang meliputi daerah pertemuan antara pengaruh perairan dan daratan, wilayah daratan yang mencakup wilayah adminstrasi kecamatan dan ke arah perairan laut sejauh 12 (dua belas) mil laut yang diukur dari garis pantai ke arah laut lepas dan atau ke arah perairan kepulauan. Adapun tujuan dari pengelolaan WP3K ini adalah:

1. Melindungi, mengonservasi, merehabilitasi, memanfaatkan, dan memperkaya sumber daya pesisir dan pulau-pulau kecil serta sistem ekologisnya secara berkelanjutan;

2. Menciptakan keharmonisan dan sinergi Antara Pemerintah dan Pemerintah Daerah dalam pengelolaan sumberdaya pesisir dan pulau-pulau kecil;

3. Memperkuat peran serta masyarakat dan lembaga pemerintah serta mendorong inisiatif masyarakat dalam pengelolaan sumber daya pesisir dan pulau-pulau kecil agar tercapai keadilan, keseimbangan, dan keberlanjutan; dan

4. Meningkatkan nilai sosial, ekonomi, dan budaya masyarakat melalui peran serta masyarakat dalam pemanfaatan sumber daya pesisir dan pulau-pulau kecil.

Secara keseluruhan UUWP3K ini terdiri dari 19 (sembilan belas) bab dengan 80 pasal. Ada pranata hukum baru dalam undang-undang ini yang dikenal dengan istilah Hak Pengusahaan Perairan Pesisir (HP3). HP3 ini adalah hak atas bagian-bagian tertentu dari perairan pesisir untuk usaha kelautan dan perikanan, serta usaha lain yang terkait dengan pemanfaatan sumber daya pesisir dan pulaupulau kecil yang mencakup atas permukaan laut dan kolom air sampai dengan permukaan dasar laut pada batas keluasan tertentu. HP3 ini diatur dalam Bab V 
tentang Pemanfaatan. HP3 ini dapat diberikan kepada orang perorangan, badan hukum yang didirikan berdasarkan hukum Indonesia dan masyarakat adat untuk jangka waktu 20 tahun dan dapat diperpanjang lagi selama 20 tahun dan seterusnya. Dalam pemberian HP3 ini, selain harus memenuhi persyaratan teknis, administrasi dan operasional, juga wajib memperhatikan kelestarian ekosistem pesisir dan pulau-pulau kecil, kepentingan masyarakat adat, kepentingan nasional serta hak lintas damai bagi kapal asing. Lingkup area yang dikecualikan dalam pemberian HP3 adalah kawasan konservasi, suaka perikanan, alur pelayaran, kawasan pelabuhan dan pantai umum. HP3 dalam Undang-Undang ini disetarakan dengan hak kebendaan yang kepemilikannya dapat dibuktikan dengan adanya sertifikat yang dapat beralih dan dialihkan, serta dijaminkan dengan hak tanggungan.

Dalam perkembangannya Undang-Undang No. 27 Tahun 2007 tentang WP3K ini dinilai oleh beberapa kalangan belum mewujudkan pendekatan Integrated Coastal Management, yang ditandai dengan tidak adanya pembaharuan atas penguasaan dan pengusahaan yang timpang dan adanya ketidaksinkronan dengan undang-undang lainnya. Undang-Undang ini juga dianggap lebih mementingkan aspek investasi dan lebih pro kepada dunia usaha sehingga tidak ada ruang bagi masyarakat, khususnya masyarakat nelayan tradisional dan masyarakat adat dalam pengusulan rencana pengelolaan WP3K. Keberadaan HP3 secara substansial dianggap dapat menghalangi akses masyarakat ${ }^{16}$ pesisir, $^{2}$ khususnya nelayan, terhadap sumber daya kelautan, baik yang ada di permukaan laut, badan air maupun di dasar laut. Dikhawatirkan semua akses terhadap sumber daya perairan dan kelautan nantinya akan dikuasai oleh investor/pemilik modal yang memiliki teknologi dan sanggup memenuhi persyaratan perundang-

16 Akses masyarakat atau akses public diartikan sebagai jalan masuk yang berupa kemudahan, Antara lain akses masyarakat dalam memanfaatkan sempadan pantai dalam menghadapi bencana maupun akses menuju pantai dalam menikmati keindahan alam, akses nelayan dan pembudi daya ikan dalam kegiatan perikanan, termasuk akses untuk mendapatkan air minum atau air bersih, akses pelayanan rakyat dan akses masyarakat untuk kegiatan keagamaan dan adat di pantai. Lihat Penjelasan Pasal 26 A ayat (4) huruf b. Undang-Undang No. 1 Tahun 2014 tentang Perubahan atas Undang-Undang No. 27 Tahun 2007 tentang Pengelolaan Kawasan Pesisir dan Pulau-pulau Kecil. 
undangan sedangkan masyarakat pesisir/nelayan tradisional kembali hanya menjadi penonton karena tidak dapat bersaing.

Hal-hal inilah yang kemudian menjadi alasan bagi beberapa lembaga swadaya masyarakat dan kelompok petani serta nelayan pada Januari Tahun 2010 mengajukan permohonan Judicial Review terhadap beberapa pasal, yaitu Pasal 1 angka 4, angka 7 dan angka 18, Pasal 14 ayat (1), Pasal 16 ayat (1) dan ayat (2), Pasal 20, Pasal 23 ayat (4), ayat (5), dan ayat (6) huruf b. dalam UUWP3K kepada Mahkamah Konstitusi. Selanjutnya Mahkamah Konstitusi melalui Putusan No.3/PUU-VIII/2010 menyatakan bahwa Pasal 1 angka 18, Pasal 16, Pasal 17, Pasal 18, Pasal 19, Pasal 20, Pasal 21, Pasal 22, Pasal 23 ayat (4) dan ayat (5), Pasal 50, Pasal 51, Pasal 60 ayat (1), Pasal 71 serta Pasal 75 dalam UndangUndang No. 27 Tahun 2007 dinyatakan bertentangan dengan UUD 1945 dan tidak mempunyai kekuatan hukum mengikat. Adapun semua perjanjian atau kontrak dan izin usaha di bidang pengelolaan WP3K yang telah ditanda tangani dan diterbitkan tetap berlaku sampai berakhirnya jangka waktu perjanjian/kontrak dan izin usaha tersebut ${ }^{17}$.

Pemerintah menilai bahwa pengelolaan WP3K selama ini belum memberikan kewenangan dan tanggung jawab Negara secara memadai atas pengelolaan perairan pesisir dan pulau-pulau kecil melalui mekanisme pemberian HP3. Namun demikian keberadaan Undang-Undang No. 27 Tahun 2007 ini dirasakan sangat strategis untuk mewujudkan keberlanjutan pengelolaan sumberdaya pesisir dan pulau-pulau kecil serta mensejahterakan masyarakat yang bertempat tinggal di wilayah pesisir dan pulau-pulau kecil. Maka dalam rangka optimalisasi pengelolaan wilayah pesisir dan pulau-pulau kecil yang sesuai dengan perkembangan kebutuhan hukum dimasyarakat, maka dilakukan perubahan atas Undang-Undang No. 27 Tahun 2007 dengan merevisi beberapa pasal di dalamnya yang kemudian dimuat dalam Undang-Undang No. 1 Tahun 2014 tentang Perubahan atas Undang-Undang No. 27 Tahun 2007 tentang

\footnotetext{
${ }^{17}$ Lihat Putusan Mahkamah Konstitusi No.3/PUU-VIII/2010.
} 
Pengelolaan Wilayah Pesisir dan Pulau-pulau Kecil dengan pertimbangan antara lain sebagai berikut ${ }^{18}$ :

1. Negara bertanggung jawab atas pengelolaan wilayah pesisir dan pulau-pulau kecil dalam bentuk penguasaan kepada pihak lain, baik perseorangan atau swasta melalui mekanisme perijinan. Pemberian ijin kepada pihak lain tersebut tidaklah mengurangi wewenang Negara untuk memberikan menyusun kebijakan (beleid), melakukan pengaturan (regelendaad), melakukan pengurusan (bestuursdaad), melakukan pengelolaan (beheersdaad), dan melakukan pengawasan (toezichthoudensdaad). Dengan demikian Negara masih tetap menguasai dan mengawasi secara utuh seluruh pengelolaan wilayah pesisir dan pulau-pulau kecil.

2. Pengelolaan wilayah pesisir dan pulau-pulau kecil dilaukan dengan tetap mengakui dan menghormati kesatuan-kesatuan Masyarakat Hukum Adat ${ }^{19}$ serta hak-hak tradisionalnya sesuai dengan prinsip Negara Kesatuan Republik Indonesia. Serta menghormati Masyarakat Lokal ${ }^{20}$ dan Masyarakat Tradisional yang bermukim di wilayah pesisir dan pulau-pulau kecil.

Pengelolaan wilayah pesisir dan pulau-pulau kecil meliputi kegiatan perencanaan, pemanfaatan, pengawasan, dan pengendalian terhadap interaksi manusia dalam memanfaatkan sumberdaya alam pesisir dan pulau-pulau kecil serta proses alamiah secara berkelanjutan dalam upaya meningkatkan kesejahteraan masyarakat dan menjaga keutuhan $\mathrm{NKRI}^{21}$. Pengelolaan tersebut

\footnotetext{
${ }^{18}$ Penjelasan Umum Undang-Undang No. 1 Tahun 2014 tentang Perubahan atas UndangUndang No. 27 Tahun 2007 tentang Pengelolaan Kawasan Pesisir dan Pulau-pulau Kecil

19 Masyarakat Hukum Adat adalah sekelompok orang yang secara turun temurun bermukim di wilayah geografis tertentu di NKRI karena adanya ikatan pada asal usul leluhur, hubungan yang kuat dengan tanah, wilayah, sumberdaya alam, memiliki pranata pemerintahan adat, dan tatanan hokum adat di wilayah adatnya sesuai dengan ketentuan peraturan perundangundangan (lihat Pasal 1.33 Undang-Undang No. 1 Tahun 2014 tentang Perubahan atas UndangUndang No. 27 Tahun 2007 tentang Pengelolaan Kawasan Pesisir dan Pulau-pulau Kecil).

${ }^{20}$ Masyarakat lokal adalah kelompok masyarakat yang menjalankan tata kehidupan sehari-hari berdasarkan kebiasaan yang sudah diterima sebagai nilai-nilai yang berlaku umum, tetapi tidak sepenuhnya bergantung pada sumberdaya Pesisir dan Pulau-pulau Kecil (lihat Pasal 1.34 Undang-Undang No. 1 Tahun 2014 tentang Perubahan atas Undang-Undang No. 27 Tahun 2007 tentang Pengelolaan Kawasan Pesisir dan Pulau-pulau Kecil).

${ }^{21}$ Lihat Pasal 5 Undang-Undang No. 1 Tahun 2014 tentang Perubahan atas Undangundang No. 27 Tahun 2007 tentang Pengelolaan Kawasan Pesisir dan Pulau-pulau Kecil.
} 
dilaksanakan dengan mengintegrasikan antara pemerintah pusat, antar pemerintah daerah, antar sektor, antara para pemangku kepentingan (pemerintah, dunia usaha dan masyarakat), antara ekosistem darat dan laut, dan antar disiplin ilmu dan manajemen. Adapun tujuan dari pengelolaan wilayah pesisir dan pulau-pulau kecil ini dilaksanakan dengan tujuan ${ }^{22}$ :

1. Melindungi, mengkonservasi, merehabilitasi, memanfaatkan, dan memperkaya sumberdaya pesisir dan pulau-pulau kecil serta system ekologisnya secara berkelanjutan.

2. Menciptakan keharmonisan dan sinergi Antara Pemerintah dan Pemda dalam pengelolaan sumberdaya pesisir dan pulau-pulau kecil.

3. Memperkuat peran serta masyarakat dan lembaga pemerintah serta mendorong inisiatif masyarakat dalam pengelolaan sumberdaya pesisir dan pulau-pulau kecil agar tercapai keadilan, keseimbangan, dan keberlanjutan, dan

4. Meningkatkan nilai sosial, ekonomi, dan budaya masyarakat melalui peran serta masyarakat dalam pemanfaatan sumberdaya pesisir dan pulau-pulau kecil

Dengan demikian pengelolaan WP3K yang meliputi tahapan perencanaan, pemanfaatan, pengawasan dan pengendalian dalam lingkup wilayah perairan laut dan daratan telah sesuai dengan ketentuan dalam Undang-Undang No. 32 Tahun 2004 tentang Pemerintahan Daerah.

2. Pengelolaan Wilayah Pesisir dan Pulau-Pulau Kecil Berdasarkan UndangUndang No. 1 Tahun 2014 tentang Perubahan atas Undang-Undang No. 7 Tahun 2007 tentang Pengelolaan Wilayah Pesisir dan Pulau-Pulau Kecil

\subsection{Tahap Perencanaan}

Berdasarkan Penjelasan Umum Undang-Undang No. 7 Tahun 2007 tentang Pengelolaan WP3K dinyatakan bahwa perencanaan dilaksanakan melalui pendekatan pengelolaan wilayah pesisir dan pulau-pulau kecil secara terpadu atau yang dikenal dengan istilah Integrated Coastal Management, yang

${ }^{22}$ Lihat Pasal 6 Undang-Undang No. 1 Tahun 2014 tentang Perubahan atas UndangUndang No. 27 Tahun 2007 tentang Pengelolaan Kawasan Pesisir dan Pulau-pulau Kecil. 
mengintegrasikan berbagai perencanaan yang disusun oleh berbagai sector terkait dan sesuai dengan tugas dan kewenangan pemerintah pusat dan daerah sehingga terjadi keharmonisan dan penguatan dalam pemanfaatan. Tahap perencanaan diatur dalam Bab IV mulai dari Pasal 7 sampai dengan Pasal 15. Berdasarkan Pasal 7, perencanaan pengelolaan wilayah pesisir dan pulau-pulau kecil terdiri atas berbagai kegiatan sebagai berikut:
a. Rencana Strategis WP3K (RS-WP3K);
b. Zonasi WP3K (RZ-WP3K);
c. Rencana Pengelolaan WP3K (RP-WP3K); dan,
d. Rencana Aksi Pengelolaan WP3K (RAP-WP3K).

Pemerintah Daerah berkewajiban menyusun semua rencana tersebut diatas, termasuk Rencana Zonasi rinci, sesuai dengan kewenangannya masingmasing dengan melibatkan masyarakat sesuai dengan norma, standar dan pedoman yang berlaku. Selanjutnya terdapat perubahan isi dalam Pasal 14 ayat (1) yang mengatur mekanisme penyusunan rencana bahwa dalam usulan penyusunan RS-WP3K, RZ-WP3K, RP-WP3K dan RAP-WP3K akan dilakukan oleh Pemerintah Daerah dan Dunia Usaha. Tidak adanya pelibatan warga masyarakat lokal dan masyarakat tradisional yang bermukim di wilayah pesisir dan pulaupulau kecil dalam penyusunan usulan rencana menjadi sorotan banyak pihak karena dianggap sebagai pengabaian hak-hak masyarakat pesisir yang seharusnya menjadi pihak yang sangat berkepentingan dalam pengelolaan WP3K. Kemudian Pasal 14 ayat (1) ini direvisi dalam Undang-Undang No. 1 Tahun 2014, bahwa usulan penyusunan RS-WP3K, RZ-WP3K, RP-WP3K dan RAP-WP3K akan dilakukan oleh Pemerintah Daerah, Masyarakat dan Dunia Usaha.

\subsection{Tahap Pemanfaatan}

Pemanfaatan wilayah pesisir dan pulau-pulau kecil antara lain diprioritaskan untuk kegiatan konservasi, pendidikan dan pelatihan, penelitian dan pengembangan, budidaya laut, pariwisata, usaha perikanan dan kelautan serta industri perikanan lestari, pertanian organik, peternakan dan kepentingan 
pertahanan dan keamanan negara. Pemanfaatan sumberdaya pesisir dan pulaupulau kecil ini dilakukan dengan menggunakan mekanisme perijinan sebagaimana diatur dalam Bab V Bagian Kesatu. Bab V inilah yang sebelumnya mengalami revisi secara radikal dengan menghapus seluruh ketentuan yang berkaitan dengan Hak Pengusahaan Perairan Pesisir (HP3) sebagai akibat dari pelaksanaan Putusan Mahkamah Konstitusi.

Selanjutnya dalam Undang-Undang No. 1 Tahun 2014 dunyatakan bahwa setiap orang yang melakukan pemanfaatan ruang dan sebagian perairan pesisir dan pemanfaatan pulau-pulau kecil secara menetap diwajibkan memiliki Izin Lokasi ${ }^{23}$. Pasal 17 Undang-Undang No. 1 Tahun 2014 mengatur mengenai pertimbangan pemberian Izin Lokasi, yaitu:

a. Pemberian Izin Lokasi disesuaikan dengan rencana zonasi wilayah pesisir dan pulau-pulau kecil,

b. Pemberian Izin Lokasi wajib mempertimbangkan kelestarian ekosistem pesisir dan pulau-pulau kecil, Masyarakat nelayan tradisional, kepentingan nasional dan hak lintas damai kapal asing.

c. Izin Lokasi diberikan untuk jangka waktu dan luasan tertentu.

d. Izin Lokasi tidak dapat diberikan pada zona inti di kawasan konservasi, alur laut, kawasan pelabuhan, dan pantai umum.

Pemberian izin lokasi ini merupakan dasar dari pemberian Izin Pengelolaan $^{24}$. Izin lokasi dan Izin Pengelolaan dapat diberikan kepada orang perorang WNI, korporasi yang berbadan hukum Indonesia dan koperasi yang dibentuk oleh masyarakat yang memenuhi persyaratan teknis, administrasi dan operasional. Pemerintah dan Pemerintah Daerah wajib memfasilitasi pemberian

\footnotetext{
${ }^{23}$ Izin lokasi adalah izin yang diberikan untuk memanfaatkan ruang dari sebagian pesisir yang mencakup permukaan laut dan kolom air sampai dengan permukaan dasar laut pada batas keluasan tertentu dan/atau untuk memanfaatkan sebagian pulau-pulau kecil (lihat Pasal 1.18 Undang-Undang No. 1 Tahun 2014 tentang Perubahan atas Undang-Undang No. 27 Tahun 2007 tentang Pengelolaan Kawasan Pesisir dan Pulau-pulau Kecil).

24 Izin Pengelolaan adalah izin yang diberikan kepada untuk melakukan kegiatan pemanfaatan sumberdaya pesisir dan pulau-pulau kecil ((lihat Pasal 1.18A Undang-undang No. 1 Tahun 2014 tentang Perubahan atas Undang-Undang No. 27 Tahun 2007 tentang Pengelolaan Kawasan Pesisir dan Pulau-pulau Kecil).
} 
Izin Lokasi dan Izin Pengelolaan kepada Masyarakat Lokal dan Masyarakat Tradisional yang akan memanfaatkan ruang dan sumberdaya perairan wilayah pesisir dan pulau-pulau kecil untuk pemenuhan kebutuhan sehari-hari. Adapun pemanfaatan ruang dan sumberdaya perairan wilayah pesisir dan pulau-pulau kecil di lingkungan wilayah Masyarakat Hukum Adat oleh Masyarakat Hukum Adat menjadi kewenangan Masyarakat Hukum Adat setempat ${ }^{25}$.

Izin Pengelolaan ini diberikan untuk kegiatan produksi garam, biofarmakologi laut, bioteknologi laut, pemanfaatan air laut selain energi, wisata bahari, pemasangan pipa dan kabel bawah laut dan pengangkatan benda muatan kapal tenggelam. Adapun pemanfaatan sumberdaya perairan wilayah pesisir dan pulau-pulau kecil dalam rangka penanaman modal asing maka ijin akan diberikan oleh Menteri Perikanan dan Kelautan setelah mendapatkan rekomendasi dari bupati atau walikota dengan tetap mengutamakan kepentingan nasional. Izin tersebut diberikan dengan syarat bahwa pemohon harus berbadan hukum perseroan terbatas, dapat menjamin akses publik, di wilayah yang tidak berpenduduk, belum ada pemanfaatan oleh masyarakat lokal, harus bekerja sama dengan peserta Indonesia, melakukan pengalihan saham secara bertahap kepada peserta Indonesia, harus melakukan alih teknologi dan memperhatikan aspek ekologi, sosial, dan ekonomi pada luasan lahan ${ }^{26}$.

Pemanfaatan ruang dari sebagian perairan pesisir dan pemanfaatan sebagian pulau-pulau kecil yang tidak sesuai dengan Izin Lokasi yang diberikan akan dikenai sanksi administrasi yang dapat berupa peringatan tertulis, penghentian sementara kegiatan, penutupan lokasi, pencabutan izin, pembatalan izin dan atau denda administratif. Pejabat yang berwenang dalam pemberian dan pencabutan $^{27}$ Izin Lokasi dan Izin Pengelolaan adalah Menteri Kelautan dan

${ }^{25}$ Lihat Pasal 20, 21, 22A dan Pasal 22B Undang-Undang No. 1 Tahun 2014 tentang Perubahan atas Undang-Undang No. 27 Tahun 2007 tentang Pengelolaan Kawasan Pesisir dan Pulau-pulau Kecil

${ }^{26}$ Lihat Pasal 19 dan Pasal 26 A Undang-Undang No. 1 Tahun 2014 tentang Perubahan atas Undang-Undang No. 27 Tahun 2007 tentang Pengelolaan Kawasan Pesisir dan Pulau-pulau Kecil

${ }^{27}$ Lihat Pasal 50 Undang-Undang No. 1 Tahun 2014 tentang Perubahan atas UndangUndang No. 27 Tahun 2007 tentang Pengelolaan Kawasan Pesisir dan Pulau-pulau Kecil 
Perikanan, Gubernur dan Bupati/Walikota tergantung wilayah yang menjadi kewenangannya masing-masing. Selain sanksi administratif, undang-undang juga menetapkan sanksi pidana penjara dan denda bagi pihak-pihak yang tidak memiliki Izin dan Izin Pengelolaan ${ }^{28}$.

Pasal 23 yang mengatur tentang pemanfaatan pulau-pulau kecil dan perairan di sekitarnya juga merupakan salah satu pasal yang mengalami revisi, khususnya dalam ayat (2) terdapat penambahan hingga sampai huruf (i) yaitu pemanfaatan pulau-pulau kecil dan perairan di sekitarnya dalam rangka pertahanan dan keamanan Negara. Penambahan ini sangatlah tepat mengingat Indonesia merupakan Negara kepulauan dan pulau-pulau kecil memiliki fungsi strategis dalam penetapan jurisdiksi wilayah NKRI dan keamanan Negara. Selanjutnya ketentuan ayat (4) hingga ayat (7) dalam Pasal 23 telah dihapus karena mengatur tentang HP3. Pasal 30 mengalami revisi terkait dengan perubahan zona inti pada wilayah konservasi untuk kegiatan eksploitasi diatur lebih rinci. Dalam Bab V tentang Pemanfaatan WP3K selain diatur tentang kegiatan pemanfaatan, juga diatur kegiatan lainnya seperti konservasi, rehabilitasi, reklamasi serta larangan.

Dalam Pasal 35 diatur mengenai berbagai larangan bagi setiap orang yang secara langsung maupun tidak langsung melakukan kegiatan antara lain seperti menambang terumbu karang sehingga dapat merusak ekosistem, mengambil terumbu karang di kawasan konservasi, melakukan berbagai kegiatan yang dapat merusak ekosistem mangrove dan padang lamun, melakukan penambangan pasir dan mineral serta minyak dan gas, serta melakukan pembangunan fisik yang dapat merusak lingkungan dan merugikan masyarakat sekitarnya. Butir-butir larangan ini seharusnya seharusnya disosialisasikan dengan intensif kepada masyarakat setempat agar tidak terkena sanksi akibat dari kurang akses mereka terhadap informasi khususnya peraturan perundang-undangan yang secara khusus mengatur aktifitas di sekitar mereka.

\footnotetext{
${ }^{28}$ Lihat Pasal 71 Undang-Undang No. 1 tahun 2014 tentang Perubahan atas UndangUndang No. 27 tahun 2007 tentang Pengelolaan Kawasan Pesisir dan Pulau-pulau Kecil
} 


\subsection{Tahapan Pengawasan dan Pengendalian}

Tahapan pengawasan dan pengendalian diatur dalam Bab VI dari Pasal 36 sampai dengan Pasal 41. Kegiatan pengawasan dan pengendalian dalam pemanfaatan WP3K dilakukan untuk menjamin terselenggaranya pengelolaan WP3K secara terpadu dan berkelanjutan. Pengawasan dan pengendalian dilakukan oleh Pejabat Pegawai Negeri Sipil tertentu yang mengelola WP3K berdasarkan Peraturan Menteri, yang dilakukan dengan:

a. Mengadakan patroli.perondaan di WP3K, serta

b. Menerima laporan yang menyangkut perusakan ekosistem pesisir, kawasan konservasi, kawasan pemanfaatan umum dan kawasan strategis nasional tertentu.

Pasal 36 ayat (5) mewajibkan Pemerintah Pusat dan Daerah untuk melakukan pemantauan, pengamatan lapangan, dan/atau evaluasi terhadap perencanaan dan pelaksanaannya. Selanjutnya masyarakat juga dapat berperan serta dalam pengawasan dan pengendalian WP3K yang dilakukan dengan penyampaian laporan dan/atau pengaduan kepada pihak yang berwenang.

Dalam rangka pengedalian dalam pemanfaatan WP3K, Pemerintah berkewajiban menyelenggarakan akreditasi terhadap program pengelolaan WP3K. Gubernur, Bupati/Walikota dan Organisasi Masyarakat atau kelompok masyarakat dapat mengajukan usulan akreditasi atas program pengelolaan WP3K kepada Pemerintah Pusat dan Daerah sesuai dengan kewenangan masing-masing. Adapun standar dan pedoman akreditasi mencakup: a) relevansi isu prioritas; b) proses konsultasi publik; c) dampak positif terhadap kelestarian alam; d) dampak terhadap peningkatan kesejahteraan masyarakat; e) kemampuan implementasi yang memadai; dan f) dukungan kenijakan dan program Pemerintah dan Pemerintah Daerah.

Dalam upaya peningkatan kapasitas para pemangku kepentingan dalam pengelolaan WP3K, undang-undang mengatur pembentukan Mitra Bahari. Mitra Bahari ini merupakan forum kerjasama antara Pemerintah dan Pemerintah daerah, 
perguruan tinggi, lembaga swadaya masyarakat, organisasi profesi, tokoh masyarakat dan dunia usaha. Kegiatan forum Mitra Bahari ini menurut Pasal 41 dapat berupa kegiatan pendampingan dan.atau penyuluhan, pendidikan dan pelatihan, penelitian terapan dan rekomendasi kebijakan. Kegiatan-kegiatan tersebut difasilitasi oleh Pemerintah dan Pemerintah Daerah.

Hak dan kewajiban masyarakat secara khusus diatur dalam Pasal 60 yang telah diubah sehingga jumlah hak masyarakat bertambah menjadi 12 hak (sebelumnya hanya 10). Beberapa hak masyarakat disini antara adalah hak untuk:

a. Memperoleh akses terhadap bagian perairan pesisir yang sudah diberi izin lokasi dan izin pengelolaan.

b. Mengusulkan wilayah penangkapan ikan secara tradisional ke dalam RZWP3K

c. Mengusulkan wilayah Masyarakat Hukum Adat ke dalam RZ-WP3K

d. Memperoleh ganti rugi

e. Memperoleh informasi dan manfaat dari pengelolaan WP3K.

f. Mengajukan laporan dan pengaduan kepada pihak yang berwenang atas kerugian yang menimpa dirinya yang berkaitan dengan pengelolaan WP3K, termasuk mengajukan ganti rugi atas peristiwa tersebut.

g. Mengajukan gugatan kepada pengadilan terhadap berbagai masalah WP3K dan mendapatkan pendampingan dan bantuan hukum sesuai dengan peraturan yang berlaku.

Selain mengatur tentang hak, Pasal 60 ini juga mengatur tentang kewajiban masyarakat dalam WP3K, diantaranya adalah:

a. Memberikan informasi berkenaan dengan pengelolaan WP3K

b. Menjaga, melindungi dan memelihara kelestarian WP3K.

c. Menyampaikan laporan terjadinya bahaya pencemaran dan/atau kerusakan lingkungan di WP3K

Secara berimbang Undang-Undang ini juga memberikan kewajiban kepada Pemerintah dan Pemerintah Daerah untuk mengakui, menghormati dan 
melindungi hak-hak masyarakat adat, masyarakat tradisional dan kearifan lokal atas WP3K yang telah dimanfaatkan secara turun temurun dan menjadikan pengakuan hak-hak masyarakat adat, masyarakat tradisional dan kearifan lokal tersebut sebagai acuan dalam pengelolaan WP3K. Pasal ini berpotensi akan menjadi macan kertas mengingat tidak dilengkapi dengan mekanisme dan bentuk pengakuan tersebut. Seharusnya secara jelas dinyatakan bahwa pengakuan dan perlindungan tersebut diberikan dalam suatu peraturan perundang-undangan. Dalam hal pemberdayaan masyarakat diatur dalam Pasal 64 ayat (2) telah mengalami perubahan dengan memberikan rincian beberapa kebutuhan mendasar yang memang sangat dibutuhkan oleh masyarakat, khususnya masyarakat pesisir dan nelayan tradisional, bahwa Pemerintah dan Pemerintah Daerah berkewajiban mendorong kegiatan usaha masyarakat melalui peningkatan kapasitas, pemberian akses teknologi dan informasi, permodalan, infrastruktur, jaminan pasar dan asset ekonomi produktif lainnya.

Undang-undang No. 7 Tahun 2007 yang kemudian diubah dengan Undang-Undang No, 1 Tahun 2014 telah dilengkapi dengan mekanisme penyelesaian sengketa, gugatan perwakilan, proses penyidikan, sanksi administrasi dan sanksi pidana. Sanksi administrasi dalam Pasal 71 UndangUndang No. 7 Tahun 2007 telah disesuaikan dan terdapat penambahan 2 (dua) ayat. Adapun bentuk sanksi administrasi dalam undang-undang ini dapat berupa: a) peringatan tertulis; b) penghentian sementara kegiatan; c) penutupan lokal; d) pencabutan izin; e) pembatalan izin dan atau f) denda administratif.

Ketentuan sanksi pidana dalam Pasal 75 telah disesuaikan dengan pemberatan sanksi bagi setiap orang yang memanfaatkan ruang dari sebagian perairan pesisir dan pemanfaatan sebagian pulau-pulau kecil yang tidak memiliki izin lokasi sebagaimana ketentuan Pasal 16 ayat (1) dipidana penjara paling lama 3 (tiga) Tahun dan denda paling banyak Rp 500.000.000,- (lima ratus juta rupiah). Ketentuan sanksi sebelumnya hanya berupa pidana kurungan paling lama 6 (enam) bulan atau denda paling banyak Rp 300.000.000,- (tiga ratus juta rupiah). Diharapkan pemberatan sanksi ini dapat membrikan efek jera. Namun yang paling 
penting adalah keberanian dan ketegasan pihak yang berwajib untuk menegakkan ketentuan undang-undang tentang WP3K kepada pihak-pihak yang melanggar.

\section{PENUTUP}

Dari pembahasan mengenai pengelolaan WP3K maka dapat diambil kesimpulan bahwa:

1. Hak-hak masyarakat tradisional, khususnya hak-hak ekonomi secara umum telah diakomodir sejak dalam proses perencanaan, pemanfaatan dan pengawasan serta pengawasan terkait dengan pengelolaan WP3K.

2. Kewajiban Pemerintah dan Pemerintah Daerah untuk mengakui keberadaan masyarakat adat, masyarakat tradisional dan kearifan lokal atas WP3K yang telah dimanfaatkan secara turun temurun tidak dinyatakan dengan jelas bagaimana bentuk pengakuan itu dituangkan sehingga berpotensi konflik dalam praktinya. Sehingga dalam penerapan pengakuan hak-hak masyarakat adat, masyarakat tradisional dan kearifan lokal tersebut sebagai acuan dalam pengelolaan WP3K ini menjadi tidak efektif.

3. Penegakan hukum tanpa pandang bulu merupakan hal yang sangat penting meskipun telah dibuat pengaturan sanksi yang berat para pihak yang melanggar. Hal ini sangat diperlukan mengingat WP3K ini merupakan wilayan yang sangat penting dan strategis baik dalam aspek sosial, ekonomi, budaya dan pertahanan serta keamanan Negara.

\section{DAFTAR PUSTAKA}

\section{BUKU DAN ARTIKEL}

Baso, Aris. Revitalisasi Pemberdayaan Masyarakat Pesisir bagi Kesejahteraan Nelayan dalam buku Membangun Sumberdaya Kelautan Indonesia. Bogor: IPB Press, 2013.

Fauzi, Akhmad. Kebijakan Perikanan dan Kelautan, Jakarta: Gramedia Pustaka Utama, 2005.

Lasabuda, Ridwan. "Pembangunan Wilayah Pesisir dan Lautan dalam Perspektif Negara Kepulauan Republik Indonesia”. Jurnal Ilmiah Platax, Vol.1-2 Januari 2013, ISSN: 2302-3589. 
Nugroho, Iwan. Ekowisata dan Pembangunan Berkelanjutan. Yogyakarta: Pustaka Pelajar, 2011.

Suyatno, Bagong. Anatomi Kemiskinan dan Strategi Penanganannya. Malang: In-Trans, 2013.

Tuwo, Ambo Tuwo. Pendekatan Ekologis dalam Pengelolaan Sumberdaya Pesisir dan Laut dalam buku Membangun Sumberdaya Kelautan Indonesia, Bogor: IPB Press, 2013

Winarno, Budi. Etika Pembangunan. Yogyakarta: Center for Academic Publising Services (CAPS), 2013.

\section{PERATURAN PERUNDANG-UNDANGAN}

Indonesia, Undang-undang No. 1 Tahun 2014 tentang Perubahan atas Undangundang No. 27 Tahun 2007 tentang Pengelolaan Kawasan Pesisir dan Pulau-pulau Kecil.

. Undang-undang No.27 Tahun 2007 tentang Pengelolaan Wilayah Pesisir dan Pulau-pulau Kecil.

.Putusan Mahkamah Konstitusi No.3/PUU-VIII/2010 